\title{
Occurrence of Mycoplasma bovigenitalium and Ureaplasma diversum in dairy cattle from to Pernambuco state, Brazil
}

\author{
[Ocorrência de Mycoplasma bovigenitalium $e$ Ureaplasma diversum em bovinos leiteiros do \\ estado de Pernambuco, Brasil]
}

\author{
A.A.M. Macêdo, J.M.B. Oliveira, B.P. Silva, J.M. Borges, L.B.F. Soares, \\ G.M. Silva, S.B. Santos ${ }^{*}$, R.A. Mota, J.W. Pinheiro-Júnior \\ Universidade Federal Rural de Pernambuco - Recife-PE
}

\begin{abstract}
The objective of this study was to conduct an investigation of Mycoplasma bovigenitalium and Ureaplasma diversum infections in cattle in the microregion of the Ipanema Valley, state of Pernambuco, Brazil. Vaginal swabs were collected from 355 breeding cows in reproductive age and were analyzed by multiplex PCR (mPCR) and culture. An epidemiological investigation of risk factors was performed for Mollicutes. mPCR analysis showed that, 9.29\% (33/355) of the cows were positive for M. bovigenitalium and $21.69 \%$ (77/355) for $U$. diversum; coinfection was observed in $2.81 \%(10 / 355)$ of the cows. The microbiological isolation showed, 81.81\% (27/33) of Mycoplasma spp. and 24.67\% (19/77) of Ureaplasma spp.. The risk factors related to Mollicutes infection identified were semi-intensive breeding system $(\mathrm{OR}=4.6)$, pasture rent $(\mathrm{OR}=3.6)$, non-isolation of animals with reproductive disorders $(\mathrm{OR}=$ 3.2), and natural mounting and artificial insemination $(\mathrm{OR}=3.5)$. There was a significant association between Mollicutes infection and abortions in the first gestational third $(\mathrm{P}=0.001)$. This is the first record of $M$. bovigenitalium and $U$. diversum infection in cows in the semiarid region of the state of Pernambuco, Brazil. Preventive measures directed to the identified risk factors can decrease the occurrence of Mollicutes in these herds.
\end{abstract}

Keywords: mPCR, mollicutes, cows, risk factors, ipanema valley

\section{RESUMO}

O objetivo deste estudo foi realizar uma investigação de Mycoplasma bovigenitalium e Ureaplasma diversum em bovinos leiteiros da microrregião do Vale do Ipanema, estado de Pernambuco, Brasil. Foram coletados suabes vaginais de 355 vacas em idade reprodutiva. As amostras foram analisadas por multiplex PCR ( $m P C R)$ e cultura. Foi realizada uma investigação dos fatores de risco para Mollicutes. Na mPCR, 9,29\% (33/355) das vacas foram positivas para M. bovigenitalium e 21,69\% (77/355) para U. diversum; coinfecção foi observada em 2,81\% (10/355) das vacas. O isolamento microbiológico mostrou crescimento de Mycoplasma spp. em 81,81\% (27/33) das amostras e em 24,67\% (19/77) para Ureaplasma spp. Os fatores de risco relacionados à infecção por Mollicutes identificados foram sistema de produção semi-intensivo $(O R=4,6)$, aluguel de pastagem $(O R=3,6)$, não isolamento de animais com desordens reprodutivas $(O R=3,2)$ e monta natural e inseminação artificial $(O R=3,5)$. Houve uma associação significativa entre a infecção por Mollicutes e abortos no primeiro terço gestacional $(P=0,001)$. Este é o primeiro relato da infecção por M. bovigenitalium e U. diversum em vacas na região semiárida do estado de Pernambuco, Brasil. As medidas preventivas direcionadas aos fatores de risco identificados podem diminuir a ocorrência de Mollicutes nesses rebanhos.

Palavras-chave: $m P C R$, Mollicutes, vacas, fatores de risco, Vale do Ipanema

Recebido em 14 de julho de 2017

Aceito em 17 de abril de 2018

* Autor para correspondência (corresponding author)

E-mail: sanbsantos@gmail.com 


\section{INTRODUCTION}

Animal mycoplasmosis is a disease caused by prokaryotes without a cell wall, which belong to the Mollicutes class. Mycoplasma bovigenitalium and Ureaplasma diversum have been associated with reproductive problems in cattle (Sanderson et al., 2000; Ghanem et al., 2013), but other species of Mycoplasma spp., such as Mycoplasma bovirhinis, Mycoplasma canadense and Mycoplasma bovis, were also identified in reproductive disorders (Pfützner and Sachse, 1996; Lysnyansky et al., 2009). M. bovis causes mastitis, infertility, endometritis, salpingitis, pneumonia, arthritis, and abortions (Pfutzner and Sachse, 1996).

Genital infections caused by Mycoplasma bovigenitalium in females is characterized by granular vulvovaginitis presenting with mucopurulent vaginal discharge, which may cause infertility, and in some cases, necrotizing endometritis (Cardoso and Vasconcellos, 2004). On the other hand, Ureaplasma diversum the infection is associated with abortion, recurrence of estrus, granular vulvovaginitis and infertility in infected herds (Miller et al., 1994).

Previous studies indicated that the occurrence of Mollicutes infection associated with reproductive problems in cattle in different countries such as Australia (Argue et al., 2013), Israel (Lysnyansky et al., 2009), and the United States of America (Sanderson et al., 2000). In Brazil, it was reported in the states of Paraíba (Santos et al., 2013), Alagoas (Oliveira Filho et al., 2005), São Paulo (Buzinhani et al., 2007), and Mato Grosso (Gaeti et al., 2014). The economic losses are associated with infertility and low reproductive performance (Junqueira et al.,2006; Cardoso and Vasconcelos, 2004).

The risk factors associated with Mollicutes infection in cattle herds are related to dietary stress, such as high milk production, excessive movement of animals (exhibition and trade cattle) (Aebi et al., 2015), and heifers and cows with lower pregnancy rate (León et al., 1995).
Considering that Mollicute infection in cattle was already diagnosed in herds from to Brazil and that there is commercial transport of these animals between Brazilian states, this study aimed to conduct an epidemiological investigation of Mycoplasma bovigenitalium and Ureaplasma diversum infections in cattle in the microregion of the Ipanema Valley, state of Pernambuco.

\section{MATERIALS AND METHODS}

The present study analyzed cattle from 18 properties distributed among the six districts of the Ipanema Valley microregion in the Pernambuco semiarid region: Águas Belas ( $\mathrm{n}=$ $3)$, Buíque $(n=3)$, Venturosa $(n=3)$, Pedra $(n=3)$, Itaiba $(n=3)$ and Tupanatinga $(n=3)$ (Figure 1). A total of 336.221 cattle (IBGE, 2007) and an expected prevalence of $65.6 \%$ were considered (Santos et al., 2013). At a significance level of $\mathrm{P}<0.05$, these parameters provided a minimum sample size (n) of 355 cows (Thrusfield, 2013). The number of animals evaluated in each herd was calculated using the formula of Astudillo (1979), based on the afore mentioned values. The properties were chosen by convenience, and the inclusion criteria was females of reproductive age group.

Vaginal mucous samples were collected after vulvar cleaning and asepsis with alcohol $\left(70^{\circ} \mathrm{GL}\right)$, by using sterile cotton swab, and transported in $3 \mathrm{~mL}$ of phosphate buffered saline (pH 7.2) (Nascimento et al., 2005). The samples were placed in an isothermal box containing recyclable ice and sent to the laboratory for processing.

An aliquot of $600 \mu \mathrm{L}$ was used for DNA extraction with a commercial kit (Promega ${ }^{\circledR}$ Wizard Genomic DNA Purification Kit Catalog A1125). Aliquots for microbiological isolation were stored in 2:1 ratio glycerol in microtubes, vortexed and stored in a freezer at $-16^{\circ} \mathrm{C}$ until use. 


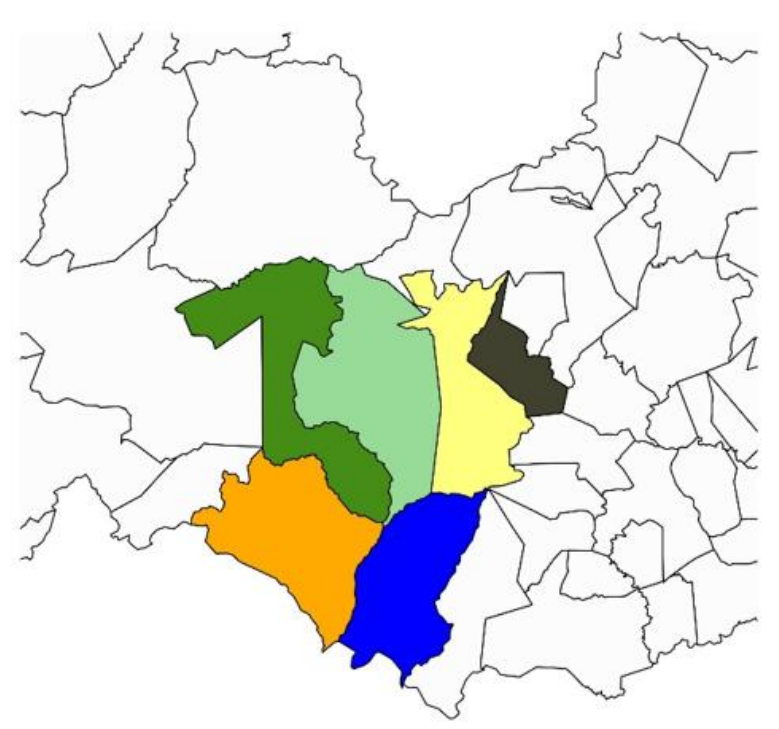

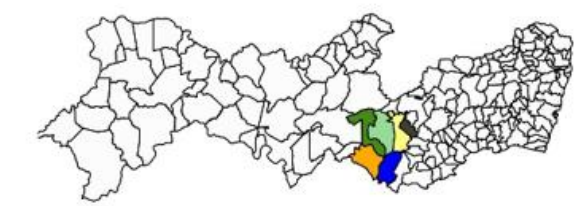

Region studied

The Ipanema Valley

- Aguas Belas

$\square$ Buique

$\square$ Itaiba

$\square$ Venturosa

$\square$ Tupanatinga

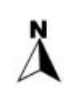

$\square$ Pedra

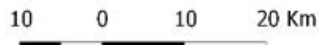

Figure 1. Area of investigation for Mollicutes in reproductive trac of cattle, microregion of the Ipanema Valley - Pernambuco-PE, Brazil.

The extracted DNA was analyzed by multiplex polymerase chain reaction ( $\mathrm{mPCR}$ ) technique for Mycoplasma bovigenitalium and Ureaplasma diversum species identification according to the thermal profile and oligonucleotides as described by Tramuta et al. (2011). The following primers were used for mPCR: Mycoplasma bovigenitalium (16S rRNA), 5'GTT TGA TCC TGG CTC AGG AT 3' and 5'AAG GTA CAT TCA ATA TAG TGG 3', with amplicon 476bp; Ureaplasma diversum (16S rRNA), 5'GTT TGA TCC TGG CTC AGG AT 3' and 5'CTC ATA AGC GAG CC GAC ATT 3', with amplicon $831 \mathrm{bp}$. The reaction mixtures comprised a total of $25 \mu \mathrm{L}$ containing $5 \mu \mathrm{L}$ DNA template, 30pmol of each oligonucleotide and $6.25 \mu \mathrm{L} \quad$ GoTaq $^{\circledR}$ Green Master Mix (Promega ${ }^{\circledR}$ Corporation, Madison, WI, USA, Ref. M7122), and ultrapure water. The Ureaplasma diversum strain (GM U132 VUP6, ATCC) and Mycoplasma bovigenitalium strain (PG11, ATCC) were used as positive control. For the negative control, the DNA template was replaced by water. For electrophoresis, $1.5 \%$ agarose gel (100V/60min), $9 \mu \mathrm{LPCR}$ reaction mixtures plus $0.3 \mu \mathrm{L}$ Blue Green Loading Dye I (LGC ${ }^{\circledR}$ Biotecnologia, Cotia, SP, Brazil) and $5 \mu$ Lof molecular size marker (100bp DNA Ladder $^{\circledR}$, LGC $^{\circledR}$ Biotecnologia, Cotia, SP, Brazil) were used. To confirm the species studied, sequencing of PCR positive samples was performed.
All the samples were screened for mycoplasma and ureaplasma by mPCR. Only mPCR confirmed isolates were further tested for recovery of pathogens using microbial culture method. Samples were cultured for Mycoplasma spp. isolation in modified Hayflick medium broth and plate, as described by Whitford et al. (1994), and for Ureaplasma spp. in UB specific medium broth and plate. The samples were observed at stereoscopic microscope and the isolation was considered positive for Mycoplasma spp. when the samples resembling "fried-egg-shaped" colonies, and the small, dark brown granular colonies, for Ureaplasma spp. All samples were monitored for 21 days.

Epidemiological questionnaires were designed and applied to obtain information about the type of farming and management practices and identify possible risk factors of each herd. The questionnaires were applied by a single trained investigator, and answed by people who could provide more about the animals. The variables investigated and the respective categories were: consortium creation (yes/no); (herds of Milk / milk and meat); Wetlands on the property (yes/no); Flooded areas on surrounding properties (yes/no); Presence of hematophagous insects (yes/no); Insect control (yes/no); Herd type (open/closed); Performs quarantine (yes/no); Reproductive management (natural breeding/artificial insemination/both). 
Univariate analysis of infection-associated risk factor was performed, by using the Pearson chisquare test $\left(\chi^{2}\right)$ or Fisher's exact test, followed by a logistic regression analysis, which considered the "Gold standard" the mPCR result for Mollicutes as the dependent variable. The independent or explanatories variables considered in the model were those with a statistical significance of $<0.20$. This probability was stipulated so that possible event risk factors were not excluded from the analysis (Hosmer and Lemeshow, 1989). The EPIINFO ${ }^{\mathrm{TM}}$ 3.5.1 program was used to perform the statistical calculations, considering as a risk factor in the final model the variables that presented statistical significance $\mathrm{P}<0.05$.
The present study was approved by the Ethics Committee on the Use of Animals (CEUA) of the Federal Rural University of Pernambuco, under license $\mathrm{N}^{\mathrm{o}} 042 / 2015$. All authors gave their consent for inclusion in this study.

\section{RESULTS AND DISCUSSION}

From the 355 samples analyzed using PCR, 9.3\% (33/355) were positive for Mycoplasma bovigenitalium and $21.7 \%$ (77/355) for Ureaplasma diversum; coinfection was present in $2.8 \%(10 / 355)$. The positive result distribution is shown in Table 1. Mycoplasma spp. growth in the Hayflick medium was $81.8 \%(27 / 33)$ and Ureaplasma spp. growth in the UB medium was $24.7 \%$ (19/77).

Table 1. Results of PCR for the M. bovigenitalium and $U$. diversum in dairy cows in the Ipanema Valley microregion, Pernambuco state, Brazil

\begin{tabular}{cccccc}
\hline Property & N & Positive mPCR & M. bovigenitalium & U. diversum & Coinfection \\
\hline A & 35 & $23(65.7 \%)$ & 7 & 13 & 3 \\
B & 33 & $24(72.7 \%)$ & 7 & 15 & 2 \\
C & 58 & $23(39.7 \%)$ & 4 & 17 & 2 \\
D & 8 & $5(62.5 \%)$ & - & 4 & 1 \\
E & 20 & $1(5.0 \%)$ & - & 1 & - \\
F & 20 & $2(10.0 \%)$ & - & 2 & - \\
G & 13 & $1(7.7 \%)$ & 1 & - & - \\
H & 8 & $6(75.0 \%)$ & - & 6 & - \\
I & 14 & $5(35.7 \%)$ & - & 4 & 1 \\
J & 14 & $3(21.4 \%)$ & 1 & 1 & - \\
K & 8 & $0(0.0 \%)$ & - & - & - \\
L & 11 & $0(0.0 \%)$ & - & - & - \\
M & 13 & $2(15.4 \%)$ & 1 & 1 & - \\
N & 17 & $2(11.7 \%)$ & - & 2 & - \\
O & 28 & $1(3.6 \%)$ & 1 & - & - \\
P & 17 & $0(0.0 \%)$ & - & - & - \\
Q & 12 & $1(8.3 \%)$ & - & 1 & - \\
R & 26 & $1(3.8 \%)$ & 1 & - & 10 \\
TOTAL & 355 & $100(28.2 \%)$ & 23 & 67 & \\
\hline
\end{tabular}

$\mathrm{N}$ - number of samples gathered at the property.

The risk factors associated with Mollicutes infection in the studied herds were semiintensive breeding system $(\mathrm{OR}=4.6, \mathrm{P}=0.040)$, $(\mathrm{OR}=3.2, \mathrm{P}<0.001)$, pasture rental performance $(\mathrm{OR}=3.6, \mathrm{P}<0.001)$, and simultaneous use of artificial insemination and natural breeding in reproductive management $(\mathrm{OR}=3.5, \mathrm{P}<0.001)$ (Table 2).
After analysis, the reproductive history of the studied herds, showed a significant association between the gestational stage in which abortion occurred $(\mathrm{P}=0.001)$ and Mollicutes infection (Table 3 ). In addition, 85 cows had a history of granular vulvovaginitis, $3.5 \% \quad(3 / 85)$ were positive for Mycoplasma bovigenitalium and $5.9 \%(5 / 85)$ were positive for Ureaplasma diversum. 
Table 2. Analysis of risk factors associated with Mollicutes infection in dairy cattle from to Ipanema Valley, Pernambuco state, Brazil

\begin{tabular}{|c|c|c|c|c|c|}
\hline Variables & $\mathrm{N}$ & $\frac{\text { mPCR }}{\text { Positive }}$ & Valor P & $\begin{array}{l}\text { Logistic regression } \\
\text { OR (I.C. } 95 \% \text { ) }\end{array}$ & Valor P \\
\hline \multicolumn{6}{|l|}{ Creation system } \\
\hline Semi-intensive & 331 & $98(29.6 \%)$ & $0.031^{(\mathrm{A})^{*}}$ & $4.6(1.0-20.0)$ & $0.040 *$ \\
\hline \multirow[t]{2}{*}{ Extensive } & 24 & $2(8.3 \%)$ & & & \\
\hline & & Animal isolation & & & \\
\hline Yes & 194 & $34(17.5 \%)$ & $<0.001^{(\mathrm{B})^{*}}$ & & \\
\hline No & 161 & $66(41.0 \%)$ & & $3.2(2.0-5.3)$ & $<0.001 *$ \\
\hline \multicolumn{6}{|c|}{ Pasture rent } \\
\hline Yes & 209 & $79(37.8 \%)$ & $<0.001^{(\mathrm{B})^{*}}$ & $3.6(2.1-6.2)$ & $<0.001 *$ \\
\hline No & 146 & $21(14.4 \%)$ & & & \\
\hline \multicolumn{6}{|c|}{ Destination of sick animals } \\
\hline Discard & 184 & $44(23.9 \%)$ & $0.064^{(\mathrm{A})}$ & & \\
\hline Remains & 171 & $56(32.7 \%)$ & & $1.5(0.9-2.4)$ & 0.065 \\
\hline \multicolumn{6}{|c|}{ Reproductive management } \\
\hline Natural mount & 243 & $54(22.2 \%)$ & $<0.001^{(\mathrm{A})^{*}}$ & - & \\
\hline Artificial insemination & 66 & $23(34.8 \%)$ & & $1.8(1.0-3.3)$ & $0.037^{*}$ \\
\hline Both & 46 & $23(50.0 \%)$ & & $3.5(1.8-6.7)$ & $<0.001 *$ \\
\hline
\end{tabular}

This is the first record of Mycoplasma bovigenitalium and Ureaplasma diversum infections in dairy cattle in the semiarid region of the state of Pernambuco, Brazil. Mollicutes identification in the reproductive tract of bovine females was reported in Brazil (Nascimento et al., 2005; Buzinhani et al., 2007; Marques et al., 2013) and different countries (Lysnyansky et al., 2009; Argue et al., 2013; Ghanem et al., 2013).
An occurrence of $9.3 \%$ for Mycoplasma bovigenitalium infection was observed in the present study. These values are simmilar to those found in Ghanem et al. (2013) study, in Japan, which found $7.4 \%$ occurrence of Mycoplasma bovigenitalium in cervical vaginal mucus samples from post-partum period of Holstein cows.

Table 3. Reproductive history associated with Mollicutes (M. bovigenitalium and $U$. diversum or both) infection in dairy cows in Ipanema Valley, Pernambuco state, Brazil

\begin{tabular}{|c|c|c|c|}
\hline \multirow{2}{*}{ Variable } & \multirow{2}{*}{$\mathrm{N}$} & mPCR & \multirow{2}{*}{ Valor $\mathrm{P}$} \\
\hline & & Positive & \\
\hline \multicolumn{4}{|c|}{ Animals with mastitis } \\
\hline Yes & 329 & $94(28.6 \%)$ & \multirow[t]{2}{*}{$0.549^{(\mathrm{A})}$} \\
\hline No & 26 & $6(23.1 \%)$ & \\
\hline \multicolumn{4}{|c|}{ Placental retention history } \\
\hline Yes & 322 & $92(28.6 \%)$ & \multirow[t]{2}{*}{$0.599^{(\mathrm{A})}$} \\
\hline No & 33 & $8(24.2 \%)$ & \\
\hline \multicolumn{4}{|c|}{ Recurrence of estrus } \\
\hline Yes & 343 & $99(28.9 \%)$ & \multirow[t]{2}{*}{$0.190^{(\mathrm{A})}$} \\
\hline No & 12 & $1(8.3 \%)$ & \\
\hline \multicolumn{4}{|c|}{ Gestation period of abortion ${ }^{1}$} \\
\hline $1 / 3$ & 55 & $24(43.6 \%)$ & \multirow[t]{3}{*}{$0.001^{(\mathrm{A})^{*}}$} \\
\hline $2 / 3$ & 149 & $29(19.5 \%)$ & \\
\hline $3 / 3$ & 73 & $17(23.3 \%)$ & \\
\hline
\end{tabular}

$\chi^{2}$ Test; $\mathrm{N}$ - Total Number of Samples; ${ }^{1}$ different database $(\mathrm{N}=277) ; *$ Significant association at the $\mathrm{P}<0.05$ level. 
The low occurrence of Mollicutes infection may be related to the low amount of DNA present in the biological material. Husted (2003) reported that the low amount of DNA in the analyzed samples may result in a low frequency of positive samples. Furthermore, the animals did not present suggestive clinical signs during the gathering, unlike the studies conducted by Santos et al. (2013; 2015) which investigated the occurrence of Mollicutes in herds with reproductive disorders.

Historically, M. bovigenitalium and Ureaplasma diversum stand out as agents involved in outbreaks of reprductive diseases in cattle, the main species being diagnosed in mycoplasmosis clinical. M. bovigenitalium have been isolated from the vaginal secretions of cows, this agent has been associated with natural cases of granular vulvovaginitis (Afshar, 1967; Lysnyansky et al., 2009).

In the present study, Ureaplasma diversum was detected in $21.7 \%(77 / 355)$ of the samples. The higher occurrence of Ureaplasma diversum infection compared to Mycoplasma bovigenitalium may be due to the agent colonization characteristic, for the reason that Ureaplasma diversum remains longer in the organism of asymptomatic animals depending on the urea concentrations in the urogenital tract excreta, which is an important nutrient for these bacteria (Sanderson et al., 2000). Although, the silent disease can manifest itself with decreases in the reproductive performance of the cattle (Argue et al., 2013; Santos et al., 2015).

In the seven properties ("A," "B," "C," "D," "H," "I," and "J"), the occurrence of positive animals was high for the agents in question. In these properties, the milk production was higher, which corroborates with Gábor et al. (2008) that reported the Mollicutes occurrence in a herd with higher milk production. Moreover, the use of natural breeding and/or artificial insemination as reproductive management may have contributed for these agents spread between the herd. According to (Nicholas and Ayling, 2003), contaminated semen is an important transmission route in bovine specie.

It was observed that $81.8 \%(27 / 33)$ of the mPCR-positive samples grew Mycoplasma spp. in the specific medium. This percentage is higher than that reported by other authors in Brazil (Nascimento et al., 2005; Buzinhani et al., 2007) who also isolated only Mycoplasma spp. The results of the present study were higher than what was reported in previous studies that isolated Mycoplasma spp. species in cattle in other countries (Petit et al., 2008; Lysnyansky et $a l ., 2009)$. In addition, the isolation of the genus is more practical than that of different Mycoplasma spp. species. About this, Nagatomo et al. (2001) inoculated several species of Mycoplasma spp. in liquid medium and found different isolation rates compared to the culture media and a sensitivity to temperature variations.

The isolation rate of Ureaplasma spp. was reported as $24.67 \%$ (19/77). In previous studies, higher results have been described (Buzinhani et al., 2007; Petit et al., 2008; Marques et al., 2013); however, in the afore mentioned research, the isolation was performed from herds with clinical signs of mycoplasmosis.

The isolation rate of Ureaplasma spp. was lower than that for Mycoplasma spp. It is possible that the presence of dead cells (Ureaplasma spp.) in the samples accounted for the lower rate of growth in the specific medium.

Natural breeding and artificial insemination were identified as risk factors associated with Mollicutes infection in the present study. Some authors confirm the presence of Ureaplasma diversum (Hobson et al., 2013) and Mycoplasma (Cardoso and Vasconcellos, 2004) in semen and indicate the importance of this transmission route for the agent's spread in cattle (Petit et al., 2008).

Animals submitted to the semi-intensive system were 4.6 times more likely to be infected by Mollicutes than those submitted to the extensive system. Santos et al. (2013) detected Mollicutes $(65.6 \%$ - 21/32) and Ureaplasma diversum $(15.6 \%$ - 5/32) in a reproductive disease outbreak where animals were reared in a semi-intensive system. In this system, the transmission of the agent by direct contact is favored (Gambarini et al., 2009) mainly at the time of milking, because the cows have the habit of smelling and licking the external genitalia of each other, which facilitates the agent's dissemination (Rocha, 2009). 
In properties with pasture rental practice, the animals are more likely to become infected by Mollicutes $(\mathrm{OR}=3.6)$, which is also true for properties where animals with reproductive problems are not isolated $(\mathrm{OR}=3.2)$. Thus, both the pasture rental practice and not isolating animals with reproductive disorders can lead to the contact of cattle with secretions and excretions from infected animals (Nicholas and Ayling, 2003).

There was an association between abortion in the first gestational third $(\mathrm{P}=0.001)$ and Mollicutes infection, and history of abortion was observed in $45.6 \%$ of the positive cows. Petit et al. (2008) indicated that the detection of Mycoplasma bovigenitalium is greater in animals with a history of abortion. Another study implicated the occurrence of abortion in the first $(25 \%)$ and third $(75 \%)$ third of gestation. Given that there are divergences between the studies related to the timing of abortion, it is suggested that experimental or observational studies be conducted with the purpose of establishing the time of pregnancy at which the cows have a higher risk of aborting when infected with Mollicutes.

It was observed that $9.41 \%(8 / 85)$ of the positive cows (3/8 for Mycoplasma bovigenitalium and 5/8 for Ureaplasma diversum) showed signs of granular vulvovaginitis during the gathering of samples. Gambarini et al. (2009) and Cardoso et al. (1997) reported that granular vulvovaginitis may be associated with the presence of Ureaplasma diversum. Oliveira-Filho et al. (2005) affirmed that the presence of Ureaplasma diversum is associated with the occurrence of granular vulvovaginitis syndrome, and it is independent of the injury extension observed in the vulvovaginal mucosa. Some animals had granules in the vulva and were negative for Mollicutes, representing 90.5\% (77/85). The clinical condition of VVG is not pathognomonic for Mollicutes infection.

\section{CONCLUSION}

This is the first record of the occurrence of $M$. bovigenitlium and $U$. diversum infection in dairy cattle in the semiarid region of Pernambuco. The semi-intensive breeding system, pasture rent, non-isolation of animals, natural mounting and artificial insemination are a risk for the occurrence of $M$. bovigenitalium and $U$. diversum in the cattle studied. Mollicutes are associated with abortions in the in the first gestational third. Preventive measures directed at these identified risk factors may contribute to a decrease in the occurrence of these agents in the herds.

\section{ACKNOWLEDGMENTS}

Coordenação de Aperfeiçoamento Pessoal de Nível Superior (Capes, Brazil) by financial support of Master Science.

\section{REFERENCES}

ABATE DE ANIMAIS, PRODUÇÃO DE LEITE, COURO E OVOS - IBGE. Instituto Brasileiro de Geografia e Estatística, 2007. Disponível em: <http://www.ibge.gov.br/home/estatistica/indica dores/agropecuaria/producaoagropecuaria/abateleite-couro-ovos_201402_publ_completa.pdf >. Acessado em: 12 dez. 2016.

AEBI, M.; VAN DEN BORNE, B.H.P.; RAEMY, A. et al.Mycoplasmabovis infections in Swiss dairy cattle: a clinical investigation. Acta Vet. Scand., v.57, p.1-10, 2015.

AFSHAR, A. Genital mycoplasmosis in cattle. Vet. Bull., v.37, p.879-884, 1967.

ARGUE, B.; CHOUSALKAR, K.; CHENOWETH, P. Presence of Ureaplasma diversum in the Australian cattle population. Aust. Vet. J., v.91, p.99-101, 2013.

ASTUDILLO, V.M. Encuestas por muestro para estúdios epidemiologicos em populaciones animales. Rio de Janeiro: Organización Panamericana de laSalud - Centro Panamericano de Fiebre Aftosa, 1979. n.12, 60p. (Serie de Manuales Didáticos).

BUZINHANI, M.; METTIFOGO, E.; BUIM, M.R. et al. Isolates of Ureaplasma diversum genotyped by single-enzyme amplified length polymorphism. Braz. J. Microbiol., v.38, p.2932, 2007.

CARDOSO, M.V.; GRASSO, L.; STEFANO, E. et al. Isolamento de Ureaplasmadiversum e Mycoplasma spp. em casos de vulvite granular bovina. Rev. Bras. Reprod. Anim., v.21, p.172$173,1997$. 
CARDOSO, M.V.; VASCONCELLOS, S.A. Importância das micoplasmoses na fertilidade de touros. Arq. Inst. Biol., v.71, p.257-265, 2004.

GÁBOR, G.; TÓTH, F.; ÓZSVÁRI, L. et al. Factors influencing pregnancy rate and late embryonic loss in dairy cattle. Reprod. Domest. Anim., v.43, p.53-58, 2008.

GAETI, J.G.L.N.; LANA, M.V.C.; SILVA, G.S. et al.Ureaplasma diversum as a cause of pustular vulvovaginitis in bovine females in Vale Guapore, Mato Grosso State, Brazil. Trop. Anim. Health Prod.,v.46, p.1059-1063, 2014.

GAMBARINI, M.L.; KUNZ, T.L.; FILHO, B.D.O. et al. Granular vulvovaginitis syndrome in nelore pubertal and post pubertal replacement heifers under tropical conditions: role of Mycoplasma spp., Ureaplasma diversum and BHV-1. Trop. Anim. Health Prod., v.41, p.14211426, 2009.

GHANEM, M.E.; HIGUCHI, H.; TEZUKA, E. et al. Mycoplasma infection in the uterus of early postpartum dairy cows and its relation to dystocia and endometritis. Theriogenology, v.79, p.180-185, 2013

HOBSON, N.; CHOUSALKAR, K.K.; CHENOWETH, P.J. Ureaplasma diversum in bull semen in Australia: its detection and potential effects. Aust. Vet. J., v.91, p.469-473, 2013.

HOSMER, D.W.; LEMESHOW, S. (Eds.). Applied logistic regression. New York: WileyInterscience Publication, 1989. 392p.

HUSTED, J.R. Bacterial and fungal organisms in the vagina of normal cows and cows with vaginitis. 2003. 29f. Dissertatin (Master's thesis), Texas A\&M University. Texas, EUA.

JUNQUEIRA, J.R.C.; ALFIERI, A.A. Falhas da reprodução na pecuária bovina de corte com ênfase para causas infecciosas. Semina: Ciências Agrárias, v.27, p.289-298, 2006.

LEÓN, B.A.; CAMPOS, E.; BOLAÑOS, H. et al.Risk factors for Ureaplasma diversum infections in cattle of a tropical environment. Rev. Biol. Trop., v.43, p.21-5, 1995.
LYSNYANSKY, I.; BRENNER, J.; ALPERT, $\mathrm{N}$. et al. Identification of Mycoplasma bovigenitalium and Mycoplasma canadense from outbreaks of granulopapular vulvovaginitis in dairy cattle in Israel. Vet. Rec., v.165, p.319-322, 2009.

MARQUES, L.M.; AMORIM, A.T.; MARTINS, H.B. et al. A quantitative TaqMan PCR assay for the detection of Ureaplasma diversum. Vet. Microbiol., v.167, p.670-674, 2013.

MILLER, R.; CHELMONSKA-SOYTA, A.; SMITS, B. et al.Ureaplasma diversum as a cause of reproductive disease in cattle. Vet. Clin. N. Am. Food Anim. Pract., v.10, p.479-490, 1994.

NAGATOMO, H.; TAKEGAHARA, Y.; SONODA, T. et al. Comparative studies of the persistence of animal mycoplasmas under different environmental conditions. Vet. Microbiol., v.82, p.223-232, 2001.

NASCIMENTO, M.G.F.; D’ANGELIS, F.H.F.; NASCIMENTO, E.R. et al. Envolvimento de micoplasmas em vacas com distúrbios reprodutivos Mycoplasmas involvement in cows with reproductive disorders. Acta Sci. Vet., v.33, p.195-199, 2005.

NICHOLAS, R.A.; AYLING, R.D. Mycoplasma bovis: disease, diagnosis, and control. Res. Vet. Sci., v.74, p. 105-112, 2003.

OLIVEIRA-FILHO, B.D.; PORTO, R.N.G.; GAMBARINE, M.L. et al. Isolamento do Ureaplasmadiversum em muco vulvovaginal de vacas leiteiras repetidoras de estro no estado de alagoas - Brasil. Arch. Vet. Sci., v.10, p.151-156, 2005.

PETIT, T.; SPERGSER, J.; AURICH, J. et al. Prevalence of chlamydiaceae and mollicutes on the genital mucosa and serological findings in dairy cattle. Vet. Microbiol.,v.127, p.325-333, 2008.

PFÜTZNER, H.; SACHSE, K. Mycoplasma bovis as an agent of mastitis, pneumonia, arthritis and genital disorders in cattle. Rev. Sci. Tech., v.15, p.1477-1494, 1996.

ROCHA, J.M.N. Micoplasmose em bovinos de aptidão leiteira: fatores predisponentes para a ocorrência e manifestação da síndrome da vulvovaginite granular. 2009. 134f. Tese (Ciência Animal) - Escola de Veterinária, Universidade Federal de Goiás, Goiana, GO. 
SANDERSON, M.W.; CHENOWETH, P.J.; YEARY, T. et al. Prevalence and reproductive effects of Ureaplasma diversum in beef replacement heifers and the relationship to blood urea nitrogen level. Theriogenology, v.54, p.401408, 2000 .

SANTOS, S.B.; PINHEIRO JÚNIOR, J.W. et al. Ocorrência de mollicutes e Ureaplasma spp. em surto de doença reprodutiva em rebanho bovino no estado da paraíba. Pesqui. Vet. Bras.,v.33, p.315-318, 2013.

SANTOS, S.B.; PINHEIRO JÚNIOR, J.W.; MOTA, R.A. et al. Recovery of Mollicutes from the reproductive tract of dairy cattle in the state of Pernambuco, Brazil. Pesqui. Vet. Bras.,v.35, p.491-496, 2015.
THURSFIELD, M. (Ed.). Veterinary epidemiology. Garsington: Wiley-Blackwell, 2013. 556p.

TRAMUTA, C.; LACERENZA, D.; ZOPPI, S. et al. Development of a set of multiplex standard polymerase chain reaction assays for the identification of infectious agents from aborted bovine clinical samples. J. Vet. Diagn. Invest.,v.23, p.657-64, 2011.

WHITFORD, H.W.; ROSENBUSCH, R.F.; LAUERMAN, L.H. (Eds.). Mycoplasmosis in animals: laboratory diagnosis. Ames: Iowa State University Press, 1994. 173p. 